\title{
Treatment of gastric ulcer with carbenoxolone sodium and oestrogens
}

\author{
R. DOLL, I. D. HILL, AND C. F. HUTTON \\ From the Statistical Research Unit, Medical Reszarch Council, and \\ Central Middlesex Hospital, London
}

EDITORIAL SYNOPSIS This is a second controlled trial of carbenoxolone sodium in the treatment of chronic gastric ulcer and confirms the beneficial experience previously reported. It is the only drug therapy for gastric ulcer which has been demonstrated conclusively to accelerate healing, which can be achieved with patients remaining up and about, often at work, and with minimum change in diet.

Many remedies have been recommended for the treatment of gastric ulcers. Few, however, have been tested in a controlled way and those that have have nearly always been found to be ineffectual. In a series of controlled trials carried out at the Central Middlesex Hospital over the last 16 years, 13 treatments have been examined and a materially beneficial effect has been observed with only three: bed rest, stopping smoking, and the administration of carbenoxolone sodium ${ }^{1}$ (Doll, 1964). This last substance is a pentacyclic triterpene prepared from the liquorice glycoside, glycyrrhizinic acid. It has an anti-inflammatory effect in animals and in some skin diseases, and produces sodium and water retention in some subjects (Doll, Hill, Hutton, and Underwood, 1962). There is, however, no obvious reason why it should help the healing of gastric ulcers, and the possibility had to be considered that the apparently beneficial results were due to unrelated factors, even though the probability of their having occurred by chance alone was extremely low $(\mathrm{P}<0.001)$. The drug, moreover, can have important side-effects, so that it was undesirable to use it widely without conclusive evidence of its value. In these circumstances we felt that it was proper to withhold the drug in the initial treatment of some patients, and we, therefore, subjected it to a second controlled trial. At the same time we took advantage of this opportunity to see if the results could be improved by adding oestrogens, which Truelove (1960) had found to help in the healing of duodenal ulcers.

${ }^{1}$ Reported previously under the proprietary name Biogastrone (disodium salt).
METHOD

Patients in whom a gastric ulcer was diagnosed radiologically and who were thought suitable for out-patient treatment were referred to a special clinic. On their first attendance they were referred for a further barium meal examination and were seen again three days later. Patients were accepted into the trial only if a gastric ulcer niche was still present and was more than 10 sq. $\mathrm{mm}$. in area in maximum profile. They were excluded if an ulcer or an ulcer scar was seen in the duodenum or if there was clinical or radiological suspicion of malignancy. Because of the side-effects noted previously, patients were also excluded if over 70 years old or if there was evidence of material heart disease or hypertension.

The remaining patients were divided into four groups according to their sex and age. Patients in each group were numbered serially and were given one of several treatments by reference to the serial numbers on a random list maintained in the hospital pharmacy. For men under 60 years of age, the treatments were: (1) carbenoxolone sodium, $100 \mathrm{mg}$. three times a day, and stilboestrol, $0.5 \mathrm{mg}$. twice a day; (2) carbenoxolone sodium and dummy tablets in place of the stilboestrol; (3) stilboestrol and dummy tablets in place of the carbenoxolone; and (4) two sets of dummy tablets. Men of 60 years and over were treated in the same way except that each dose of carbenoxolone sodium was reduced to $75 \mathrm{mg}$. Women over 60 years were treated like men of the same ages, save that oestriol $0.5 \mathrm{mg}$. was substituted for the stilboestrol. For women under 60 years, the oestrogen treatment and the corresponding dummy tablets were omitted.

Neither the physician (R.D.) nor the radiologist (C.F.H.) knew which treatments had been given to individual patients until after the end of the trial, except in a few instances in which the development of sideeffects made it desirable to find out. 
All patients were advised to continue at work, if at all possible; to take a normal diet apart from avoiding fried food; to eat, or drink a glass of milk, at least every three hours; and to stop smoking. They were also given antacid tablets to take as necessary for the relief of pain.

Patients were seen weekly and the treatment was continued for four weeks, unless there was evidence of significant side-effects when the dose of carbenoxolone sodium was reduced or stopped. Rapid or persistent gain in weight or the development of dyspnoea or ankle oedema were treated by adding a daily dose of hydrochlorthiazide $50 \mathrm{mg}$. and potassium chloride $1 \mathrm{~g}$.

A further barium meal examination was made after five weeks and the trial period was completed three days later. The results were assessed by the change in size of the ulcer niche and the numbers of days on which the patients complained of pain.

\section{RESULTS}

One hundred and two patients were referred for treatment, but 56 were considered unsuitable for the trial and were excluded for the following reasons.

\begin{tabular}{lc} 
Reason for Exclusion & No. of Patients \\
\hline Crater healed & 20 \\
Crater less than 10 sq. mm. in cross-section & 12 \\
Crater unmeasurable & 2 \\
Crater double & 2 \\
Crater combined with duodenal ulcer & 2 \\
Surgery indicated & 2 \\
Heart disease, including hypertension & 6 \\
Patient over 70 years of age & 8 \\
Patient did not wish to attend & 2 \\
Total & 56
\end{tabular}

CARBENOXOLONE SODIUM Of the remaining patients, 24 were randomly allocated to the carbenoxolone sodium series and 22 to the control. In two patients, both treated with carbenoxolone sodium, the last barium meal examination was unavoidably delayed for between three and seven days and in two patients (one in each series) it was brought forward by a similar period. All treatment was stopped after three days in one patient on carbenoxolone sodium because of severe retrosternal pain necessitating admission to hospital, and the drug was stopped for one or more weeks after a fortnight's treatment in four others who developed dyspnoea or oedema. In a further eight patients the dose was reduced or a diuretic was added. Treatment with inert tablets was not stopped in any patient, but the dose was reduced or a diuretic was added in three patients who were suspected of showing side-effects.

The results, assessed by the change in the size of the ulcer niche, are shown in Table $I$ in comparison with those obtained in the previous trial (Doll et al., 1962). In each trial about $40 \%$ of the ulcers healed in the patients given carbenoxolone sodium ${ }^{1}$, but proportionately more ulcers healed in the control series in the second trial $(27 \%)$ than in the first $(5 \%)$. The average amount of healing was, however, closely similar on both occasions, 72 and $78 \%$ in the carbenoxolone sodium series and 35 and $39 \%$ in the control.

Both trials showed a substantial advantage for the patients given the specific drug. Ranked in order of the amount of healing, Wilcoxon's test (Wilcoxon, 1945) showed that the probability of obtaining so much separation of the groups by

${ }^{1}$ Ten of the patients in the first trial were given carbenoxolone acid in place of the disodium salt.

TABLE I

RESULTS OF TREATMENT WITH CARBENOXOLONE ASSESSED BY CHANGE IN SIZE OF ULCER IN THE FIRST AND SECOND TRIALS Trial Treatment Average Reduction

\begin{tabular}{ll} 
& \\
\hline First (Doll et al., 1962) & $\begin{array}{l}\text { Carbenoxolone (30) } \\
\text { Inert tablet (20) } \\
\text { Carbenoxolone (24) } \\
\text { Second }\end{array}$ \\
$\begin{array}{l}\text { Inert tablet (22) } \\
{ }^{1} \text { No. of patients. }\end{array}$
\end{tabular}
Ulcer Healed Reducti
$(\%)$ in Size of Ulcer $(\%)$

$67-99 \quad 34-66 \quad 33$ orless

No. of patients.

TABLE II

\begin{tabular}{|c|c|c|c|c|c|}
\hline Trial & Treatment & $\begin{array}{l}\text { No. of Patients Pain-free } \\
\text { Throughout }\end{array}$ & 1-6 Days & 7 or More Days & $\begin{array}{l}\text { Average No. of Days } \\
\text { of Pain }\end{array}$ \\
\hline $\begin{array}{l}\text { First (Doll et al., 1962) } \\
\text { Second }\end{array}$ & $\begin{array}{l}\text { Carbenoxolone (30)1 } \\
\text { Inert tablet (20) } \\
\text { Carbenoxolone (24) } \\
\text { Inert tablet (22) }\end{array}$ & $\begin{array}{r}11 \\
7 \\
7 \\
11\end{array}$ & $\begin{array}{r}12 \\
5 \\
7 \\
5\end{array}$ & $\begin{array}{r}7 \\
8 \\
10 \\
6\end{array}$ & $\begin{array}{l}5 \cdot 3 \\
7 \cdot 3 \\
9 \cdot 0 \\
4 \cdot 4\end{array}$ \\
\hline
\end{tabular}


chance factors alone was very small. In the first trial the probability was less than 0.001 ; in the second, the probability of obtaining so much separation in the same direction was 0.006 . If the one patient in the second trial who received the specific treatment for only three days (and whose ulcer healed by only $49 \%$ ) is omitted, the probability is even smaller (0.005).

The average number of days with pain in the second trial was twice as great in the carbenoxolone sodium series as in the controls (Table II), but the difference is not quite statistically significant $(0.1>P>0.05)$; in view of the fact that the difference was in the opposite direction in the first trial, we regard this as a chance effect.

In view of the general similarity between the results in the two trials, it is extremely difficult to believe that the greater amount of healing in the carbenoxolone sodium series can have been anything other than a direct effect of the treatment.

The results cannot be attributed to bias on the part of either the patients or the observers. The trial was, admittedly, not wholly 'double blind' because the appearance of side-effects suggested the method of treatment in half the carbenoxolone sodium series. Beneficial results were, however, not limited to this group and if the 16 patients who were suspected of showing a side-effect or who were given a diuretic because of rapid gain in weight are omitted, the results are equally striking. Among the remaining 11 patients in the carbenoxolone sodium series, the average reduction in the size of the ulcer niche was $74 \%$; among the 19 similar patients in the control series it was $32 \%$.

The very minor variation in the timing of the barium meal examinations can hardly have been important. The two patients in the carbenoxolone sodium series in whom the examination was delayed will presumably have shown somewhat more healing than if they had been radiographed at the planned time; but the difference is unlikely to have affected the average rate of healing by more than $1 \%$. In the control patient in whom the examination was carried out too soon, the ulcer had already healed.

The comparability of the patients before the start of treatment and in the extent to which they received ancillary treatments is illustrated in Table III. The differences between the two groups of patients are, in general, small. As in the previous trial, there was a tendency for the patients given carbenoxolone sodium to modify their smoking habits more than the patients in the control series and this could have been one factor contributing to the results. In fact, the results were closely similar to those in the first trial and changes in smoking
TABLE III

COMPARABILITY OF PATIENTS IN CARBENOXOLONE AND CONTROL SERIES

\begin{tabular}{|c|c|c|}
\hline \multirow[t]{2}{*}{ Characteristics } & \multicolumn{2}{|c|}{ No. of Patients Given } \\
\hline & $\begin{array}{l}\text { Carben- } \\
\text { oxolone } \\
\text { Sodium }\end{array}$ & $\begin{array}{l}\text { Inert } \\
\text { Tablet }\end{array}$ \\
\hline $\begin{array}{l}\text { Sex } \\
\text { Male } \\
\text { Female }\end{array}$ & $\begin{array}{r}15(63 \%) \\
9(38 \%)\end{array}$ & $\begin{array}{r}13(59 \%) \\
9(41 \%)\end{array}$ \\
\hline $\begin{array}{l}\text { Age } \\
\text { Under } 50 \text { years } \\
50-59 \text { years } \\
60 \text { years or more }\end{array}$ & $\begin{array}{l}7(29 \%) \\
8(33 \%) \\
9(38 \%)\end{array}$ & $\begin{array}{l}9(41 \%) \\
7(32 \%) \\
6(27 \%)\end{array}$ \\
\hline $\begin{array}{l}\text { Length of history without remis } \\
\text { more than } 1 \text { year } \\
\text { Under } 1 \text { year } \\
1-4 \text { years } \\
5 \text { years or more }\end{array}$ & $\begin{array}{l}9(38 \%) \\
8(33 \%) \\
7(29 \%)\end{array}$ & $\begin{array}{l}8(36 \%) \\
9(41 \%) \\
5(23 \%)\end{array}$ \\
\hline $\begin{array}{l}\text { Size of ulcer niche } \\
\text { Under } 25 \text { sq. } \mathrm{mm} \text {. } \\
25-49 \text { sq. } \mathrm{mm} \text {. } \\
50-99 \text { sq. } \mathrm{mm} \text {. } \\
100 \text { sq. } \mathrm{mm} \text {. or more }\end{array}$ & $\begin{array}{l}5(21 \%) \\
7(29 \%) \\
8(33 \%) \\
4(17 \%)\end{array}$ & $\begin{array}{l}5(23 \%) \\
5(23 \%) \\
7(32 \%) \\
5(23 \%)\end{array}$ \\
\hline $\begin{array}{l}\text { Response to advice about smoki } \\
\text { Stopped or almost stopped } \\
\text { Reduced by more than half } \\
\text { Other response } \\
\text { Not applicable (non-smokers) }\end{array}$ & $\begin{array}{l}12(50 \%) \\
7(29 \%) \\
2(8 \%) \\
3(13 \%)\end{array}$ & $\begin{array}{l}9(41 \%) \\
3(14 \%) \\
5(23 \%) \\
5(23 \%)\end{array}$ \\
\hline $\begin{array}{l}\text { Hormone treatment } \\
\text { Stilboestrol } \\
\text { Oestriol } \\
\text { None }\end{array}$ & $\begin{array}{r}7(29 \%) \\
2(8 \%) \\
15(63 \%)\end{array}$ & $\begin{array}{r}6(27 \%) \\
2(9 \%) \\
14(64 \%)\end{array}$ \\
\hline Total patients & $24(100 \%)$ & $22(100 \%)$ \\
\hline
\end{tabular}

${ }^{1}$ Averaging less than one cigarette a day throughout treatment.

habits seemed to make very little difference. Patients who received carbenoxolone sodium did better than the other patients in each smoking category (Table IV), and, despite the paucity of numbers, the difference in the average reduction in ulcer size was statistically significant in one category (for men who stopped smoking, $P=0.047$ ).

TABLE IV

RESULTS OF TREATMENT WITH CARBENOXOLONE IN RELATION TO CHANGES IN SMOKING HABITS

\begin{tabular}{|c|c|c|}
\hline \multirow[t]{2}{*}{ Smoking Category } & \multicolumn{2}{|c|}{$\begin{array}{l}\text { Average Percentage Reduction } \\
\text { in Size of Ulcer Niche }\end{array}$} \\
\hline & $\begin{array}{l}\text { Patients Given } \\
\text { Carbenoxolone }\end{array}$ & $\begin{array}{l}\text { Patients Given } \\
\text { Inert Tablet }\end{array}$ \\
\hline $\begin{array}{l}\text { Smokers who stopped or almost } \\
\text { stopped }\end{array}$ & $75(12)^{1}$ & $32(9)$ \\
\hline $\begin{array}{l}\text { Smokers who reduced by more than } \\
\text { half the previous amount }\end{array}$ & 87 (7) & $62(3)$ \\
\hline Other smokers & $100(2)$ & $60(5)$ \\
\hline $\begin{array}{l}\text { Non-smokers before start and } \\
\text { throughout }\end{array}$ & $57(3)$ & $16(5)$ \\
\hline
\end{tabular}

'No. of patients. 
Undesired side-effects were again observed in this study in a substantial proportion of cases. Five $(21 \%)$ of the 24 patients given carbenoxolone sodium developed oedema of the ankles, a proportion similar to that in the first trial $(17 \%)$. Four complained of dyspnoea, including two who developed oedema, and one patient with dyspnoea showed congestion of the veins of the neck. All seven patients had gained weight before the onset of these symptoms, the amount varying from $3 \frac{1}{2} \mathrm{lb}$. (in a woman of 67 years) to $10 \mathrm{lb}$. (in a woman of 52 years), the average being $6 \mathrm{lb}$. Symptoms usually appeared during the second or third week of treatment, but one patient became dyspnoeic with slight oedema during the first week and one was free of symptoms until the fourth. Albuminuria was not detected in any patient. Regular measurements of blood pressure were not made at the beginning of the study and repeat observations are available for only three of the patients; all of these showed increases of between 10 and $25 \mathrm{~mm}$. $\mathrm{Hg}$ systolic and 0 and $30 \mathrm{~mm}$. $\mathrm{Hg}$ diastolic. At a later stage, blood pressure was recorded weekly in all patients and a comparison between nine patients on carbenoxolone sodium and 10 not on the drug is shown in Figure 1. The mean maximum increase of pressure over the pre-treatment reading was $20 \mathrm{~mm}$. $\mathrm{Hg}$ systolic and $12 \mathrm{~mm}$. $\mathrm{Hg}$ diastolic for the carbenoxolone sodium group, and $8 \mathrm{~mm}$. systolic and $3 \mathrm{~mm}$. diastolic for the control group. Glycyrrhizinic acid and extracts of liquorice have been shown to produce sodium and water retention and potassium excretion in man (Borst, ten Holt, de Vries, and Molhuysen, 1953; Salassa, Mattox, and Rosevear, 1962) and carbenoxolone sodium to produce sodium and water retention in rats (Finney and Tárnoky, 1960), and these effects can reasonably be attributed to this action. Tárnoky and Hausmann (1964) (personal communication), however, failed to find any evidence of sodium retention after two weeks' treatment with carbenoxolone sodium in man, although they did find hypokalaemia and hypertension.

Other symptoms associated with treatment are less clearly due to the drug. Headache accompanied by increase in weight was reported by two patients on carbenoxolone sodium. One had gained $9 \frac{1}{2} \mathrm{lb}$. and also complained of dyspnoea: the other, who had never previously suffered from headache, had four days' moderately severe pain associated with a gain of $4 \mathrm{lb}$. in weight during the second week. Unusual temporary headache, severe enough to arouse the suspicion that it might be due to the drug, was also noted in one patient in the control series.

Heartburn, immediately after taking the tablets, was reported by one patient on carbenoxolone sodium and another patient, who had originally been on inert tablets, had it so severely when he switched to carbenoxolone sodium, after completing his course of treatment, that the tablets had to be stopped. Four out of 58 patients in the first trial complained of heartburn and it seems certain that this symptom can be produced by the drug. Other patients, in both treatment and control series, complained of mild heartburn which was less obviously related to the tablets, but it is possible that the drug was responsible for the symptoms in some instances.

One man, aged 61 years, complained of a continuous heavy pain across the chest radiating to the jaw and elbows which began in bed at night after three days' treatment with carbenoxolone sodium. He was admitted to hospital as a possible case of coronary thrombosis and the pain cleared within 24 hours. An E.C.G. suggested posterior ischaemia,

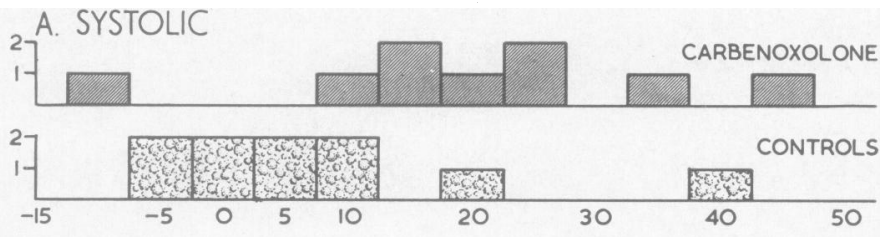

B. DIASTOLIC

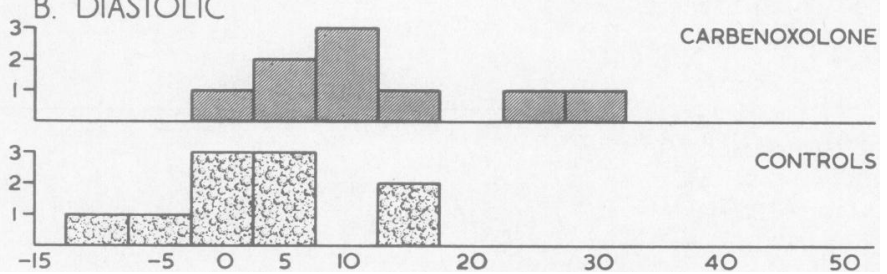

MAXIMUM BLOOD PRESSURE DURING 5 WEEKS OBSERVATION LESS INITIAL READING (mm.Hg)
FIG. 1. Maximum blood pressure during five weeks' observation less initial reading. 
but a second E.C.G. three days later showed improvement and the serum transaminose (31 units) and E.S.R. ( $3 \mathrm{~mm}$.) were normal. He was discharged 19 days later as a case of 'acute coronary insufficiency'. A year later he had had no further pain and the diagnosis remains in doubt. No similar reaction has been seen in any other patient under treatment with the drug and the association may have been coincidental.

The reason for the beneficial effect of the drug is not known. It may act through a non-specific reduction in inflammation or by stimulating the secretion of mucus.

OESTROGENS The data are re-examined in Table $V$ to show the results obtained with and without the addition of stilboestrol (in men) or oestriol (in women over 60 years). When the patients who were given oestrogens are grouped together, including those who were given carbenoxolone sodium and those who were not, it is seen that they fared somewhat better than the control patients $(73 \%$ average reduction in the size of the ulcer niche compared with $57 \%$ ). The numbers of cases are, however, small, the benefit is less marked than with carbenoxolone sodium, and the difference, though compatible with an appreciable effect, is not statistically significant.

Few other data on the use of oestrogens for gastric ulcer are available. In his review of the literature Truelove (1960) noted that 'Korbsch (1937) treated four men with gastric ulcer with intramuscular injections of an oestrogen, and obtained such rapid healing of the ulcers that he referred to the results as astounding'. Other workers have described their use only in 'peptic' or duodenal ulcers. In Truelove's series, the effect on duodenal ulcers of less than 10 years' standing was substantial: 19 out of 24 ulcers $(79 \%)$ showed prolonged clinical remission with radiological healing against eight out of 24 $(33 \%)$ in the control group.

Truelove used the same dose of stilboestrol $(0.5 \mathrm{mg}$. twice a day), but he gave it daily for six months and the effect on sexual activity was marked.
Diminution or loss of sexual potency was usual and gynaecomastia also occurred, the latter being of minor importance and not appearing until about the fourth or fifth month of treatment. In the present study oestrogens were given for only four weeks. None of the 13 men given stilboestrol volunteered information about loss of potency, but two complained of soreness of the breasts, in each case several weeks after the treatment had stopped. No complications were associated with the use of oestriol. Oestrogens did not seem to increase the risk of water retention associated with the use of carbenoxolone sodium; three of the nine patients given both drugs complained of oedema or dyspnoea, whereas the same symptoms were noted by four of the 15 patients given carbenoxolone sodium alone.

\section{SUMMARY}

The effects of carbenoxolone sodium and of oestrogens on the healing of gastric ulcers have been assessed in a controlled trial, in which patients were allocated to the treatment groups by a form of restricted randomization.

All patients were treated ambulantly; 24 were given carbenoxolone sodium (75 or $100 \mathrm{mg}$. three times a day) and 22 were given inert tablets. Treatment was continued for four weeks and the results were assessed by the change in size of the ulcer niche and by the number of days on which the patient complained of pain. Among the patients given the active drug, the ulcer healed completely in 10 $(42 \%)$ and, on average, the size of the niche was reduced by $78 \%$. Among the patients given the inert tablets the ulcer healed completely in six $(27 \%)$ and, on average, the size of the niche was reduced by $39 \%$.

These results are similar to those of a previous trial and the probability of obtaining so much difference between the groups, in the same direction as previously, by chance factors alone, is small $(P<0.01)$.

Pain disappeared quickly in nearly all patients and there was no significant difference between the

TABLE V

Patients

RESULTS OF TREATMENT WITH OESTROGENS

Average Reduction in Size of Ulcer (\%)

Patients Treated with Patients Not Treated with All Patients

Carbenoxolone

Carbenoxolone

\begin{tabular}{|c|c|c|c|c|}
\hline All men & $\begin{array}{l}\text { Stilboestrol } \\
\text { Inert tablet }\end{array}$ & $\begin{array}{l}93(7)^{1} \\
74(8)\end{array}$ & $\begin{array}{l}63(6) \\
56(7)\end{array}$ & $\begin{array}{l}79 \\
66\end{array}$ \\
\hline Women 60 years or more & $\begin{array}{l}\text { Oestriol } \\
\text { Inert tablet }\end{array}$ & $\begin{array}{r}87(2) \\
-3(1)\end{array}$ & $\begin{array}{r}19(2) \\
-16(1)\end{array}$ & $\begin{array}{r}53 \\
-9\end{array}$ \\
\hline Women 60 years or more and all men & $\begin{array}{l}\text { Oestrogen } \\
\text { Inert tablet }\end{array}$ & $\begin{array}{l}91(9) \\
65(9)\end{array}$ & $\begin{array}{l}52(8) \\
47(8)\end{array}$ & $\begin{array}{l}73 \\
57\end{array}$ \\
\hline
\end{tabular}

${ }^{1}$ No. of patients. 
groups in the number of days on which pain was noted.

Seven patients given carbenoxolone sodium developed ankle oedema or dyspnoea accompanied by an average gain of $6 \mathrm{lb}$. in weight. Blood pressure was commonly increased during treatment and these effects are attributed to a retention of sodium and water. Rarer side-effects included headache and heartburn.

Male patients received in addition stilboestrol, $0.5 \mathrm{mg}$., or a second set of inert tablets twice a day; women aged 60 years or over received a similar treatment save that oestriol $0.5 \mathrm{mg}$. was substituted for the stilboestrol. On average the ulcer healed by $73 \%$ in the 17 patients given oestrogens and by $57 \%$ in the 17 patients given inert tablets. This difference between the groups is not statistically significant.

It is concluded that carbenoxolone sodium facilitates the healing of gastric ulcers. Oestrogens may also have a beneficial effect but the present data are inconclusive.
We are grateful to our colleagues at the Central Middlesex Hospital and especially to Dr. F. Avery Jones and to Dr. T. D. Kellock for referring patients to us for treatment, to Biorex Laboratories for supplies of carbenoxolone sodium and inert tablets, and to Organon Laboratories for supplies of stilboestrol, oestriol, and inert tablets.

\section{REFERENCES}

Borst, J. G. G., Holt, S. P. ten, Vries, L. A. de, and Molhuysen, J. A. (1953). Synergistic action of liquorice and cortisone in Addison's and Simmonds's disease. Lancet, 1. 657-663.

Doll, R. (1964). Medical treatment of gastric ulcer. Scot. med. J., 9, 183-196.

-, Hill, I. D., Hutton, C., and Underwood, D. J., II (1962). Clinical trial of a triterpenoid liquorice compound in gastric and duodenal ulcer. Lancet, 2, 793-796.

Finney, R. S. H., and Tárnoky, A. L. (1960). The pharmacological properties of glycyrrhetinic acid hydrogen succinate (disodium salt). J. Pharm. Pharmacol., 12, 49-58.

Korbsch, R. (1937). Heilungen von Magenulzera durch Follikelhormon-Injektionen. Dtsch. med. Wschr., 63, 599.

Salassa, R. M., Mattox, V. R., and Rosevear, J. W. (1962). Inhibition of the 'mineralocorticoid' activity of licorice by spironolactone. J. clin. Endocr., 22, 1156-1159.

Tárnoky, A. L., and Hausmann, W. (1964). Personal communication.

Truelove, S. C. (1960). Stilboestrol, phenobarbitone, and diet in chronic duodenal ulcer. Brit. med. J., 2, 559-566.

Wilcoxon, F. (1945). Individual comparisons by ranking methods. Biomet. Bull, 1, 80-83. 